\title{
Validation of a stroke symptom questionnaire for epidemiological surveys
}

\section{Validação de um questionário de sintomas cerebrovasculares para inquéritos epidemiológicos}

\author{
Ivana Makita Abe', Alessandra Carvalho Goulart", Waldyr Rodrigues Santos Júnior"l", Paulo Andrade Lotufo", Isabela Martins Benseñor \\ Hospital Universitário (HU), Faculdade de Medicina da Universidade de São Paulo (FMUSP), São Paulo, Brazil
}

\section{KEY WORDS:}

Stroke.

Validation studies.

Population surveillance.

Prevalence.

Cross-sectional studies.

PALAVRAS-CHAVE:

Acidente vascular cerebral. Estudos de validação.

Vigilância da população.

Prevalência.

Estudos transversais.

\begin{abstract}
CONTEXT AND OBJECTIVE: Stroke is a relevant issue within public health and requires epidemiological surveillance tools. The aim here was to validate a questionnaire for evaluating individuals with stroke symptoms in the Stroke Morbidity and Mortality Study (Estudo de Mortalidade e Morbidade do Acidente Vascular Cerebral, EMMA), São Paulo, Brazil.

DESIGN AND SETIING: This was a cross-sectional study performed among a sample of the inhabitants of Butantã, an area in the western zone of the city of São Paulo.

METHODS: For all households in the coverage area of a primary healthcare unit, household members over the age of 35 years answered a stroke symptom questionnaire addressing limb weakness, facial weakness, speech problems, sensory disorders and impaired vision. Thirty-six participants were randomly selected for a complete neurological examination (gold standard).

RESULTS: Considering all the questions in the questionnaire, the sensitivity was $72.2 \%$, specificity was $94.4 \%$, positive predictive value was $92.9 \%$ and negative predictive value was $77.3 \%$. The positive likelihood ratio was 12.9 , the negative likelihood ratio was 0.29 and the kappa coefficient was 0.67. Limb weakness was the most sensitive symptom, and speech problems were the most specific.

CONCLUSIONS: The stroke symptom questionnaire is a useful tool and can be applied by trained interviewers with the aim of identifying communitydwelling stroke patients, through the structure of the Family Health Program.
\end{abstract}

\section{RESUMO}

CONTEXTO E OBJETIVO: A doença cerebrovascular como parte da agenda de saúde pública necessita de instrumentos de vigilância epidemiológica. 0 objetivo foi validar um questionário para avaliação individual de sintomas de acidente vascular cerebral através do Estudo de Morbidade e Mortalidade no Acidente Vascular Cerebral (EMMA), São Paulo, Brasil.

TIPO DE ESTUDO E LOCAL: Estudo transversal realizado em uma amostra de habitantes do Butantã, uma área na zona oeste da cidade de São Paulo. MÉTODOS: Em todos os domicílios de área adstrita de uma unidade básica de saúde, moradores com mais de 35 anos responderam questionário de sintomas de acidente vascular cerebral enfocando fraqueza de membros e facial, dificuldade em falar, alteração de sensibilidade e déficit de visão. Foram selecionadas 36 participantes aleatoriamente para exame completo com neurologista (padrão-ouro).

RESULTADOS: Considerando todas as questões do questionário, a sensibilidade foi de $72,2 \%$, a especificidade, $94,4 \%$ e os valores preditivos foram 92,9\% (positivo) e 77,3\% (negativo). As razões de verossimilhança foram 12,9 (positiva) e 0,29 (negativa) e o coeficiente kappa obtido foi 0,67. Fraqueza de membros foi o sintoma mais sensivel e dificuldade para falar, o mais específico.

CONCLUSÃo: 0 questionário de sintomas cerebrovasculares é um instrumento útil, e pode ser aplicado por entrevistadores treinados com intuito de identificar pacientes que sofreram evento cerebrovascular na comunidade através da estrutura do Programa Saúde da Família.

\section{INTRODUCTION}

During the last two decades, several epidemiological papers have indicated that cerebrovascular diseases are a public health issue in Brazil..$^{1-16}$ The impact of cerebrovascular diseases matters not only because of the burden of death ${ }^{1-8}$ and the costs of hospitalizations, ${ }^{9}$ but also because of the late effects from the disease, such as the degree of motor disabilities, post-stroke depression, reduced cognitive function and, consequently, the reduced quality of life among stroke survivors and their caregivers. ${ }^{10-12}$ However, mortality data has a natural limitation; classical prevalence surveys ${ }^{13}$ are relatively expensive; and incidence-based population studies ${ }^{14-16}$ are only suitable for small and middle-size towns. Recently, in parallel with cross-sectional studies using the traditional multistage cluster approach, new technologies for

'PhD. Attending physician, Hospital Universitário (HU), Faculdade de Medicina da Universidade de São Paulo (FMUSP), São Paulo, Brazil.

"PhD. Epidemiologist, Hospital Universitário (HU), Hospital das Clínicas (HC), Faculdade de Medicina da Universidade de São Paulo (FMUSP), São Paulo, Brazil.

'I'MD. Neurologist, Hospital das Clínicas (HC), Faculdade de Medicina da Universidade de São Paulo (FMUSP), São Paulo, Brazil.

"PhD. Professor of Clinical Medicine and Epidemiology, Faculdade de Medicina da Universidade de São Paulo (FMUSP), and Superintendent of Hospital Universitário (HU), Faculdade de Medicina da Universidade de São Paulo (FMUSP), São Paulo, Brazil.

`PhD. Attending physician, Hospital das Clínicas (HC), Faculdade de Medicina da Universidade de São Paulo (FMUSP), and Hospital Universitário (HU), Faculdade de Medicina da Universidade de São Paulo (FMUSP), São Paulo, Brazil. 
gauging the frequencies of diseases and disabilities have emerged, such as telephone surveys ${ }^{17}$ and household inquiries conducted by community health workers within primary care settings. ${ }^{18}$ One challenge in developing a cerebrovascular disease surveillance system will be to acquire appropriate tools, as shown in the World Health Organization stepwise approach to stroke surveillance (WHO Steps Stroke). ${ }^{19,20}$

Steps-Stroke is a strategy for improving the research data on stroke. It has the aim of investigating the impact of cerebrovascular diseases in relation to three steps in the disease process. ${ }^{19,20}$ Step 1 is a hospital-based phase in which determinants of the acute event are investigated, stroke subtypes are identified and the early and late case-fatality rates and disability rates are calculated by applying the modified Rankin questionnaire and the short version of Barthel's index. Step 2 is a community-based fatal stroke event register for identifying cases in which the patient either did not seek medical care or died before hospitalization. Finally, step 3 is a community-based non-fatal stroke event register that was originally designed to investigate both the incidence and the prevalence of cerebrovascular diseases. Improvements in the methods for investigating the prevalence of stroke are crucial for quantifying the real burden of stroke. Such methods need to be suitable and feasible for carrying out sequential cross-sectional studies that address a particular healthcare issue, such as the number of stroke survivors and the level of disability due to the stroke. Thus, a questionnaire identifying stroke symptoms derived from the Steps Stroke approach, with scientific validation, that can be implemented repeatedly within primary care settings at low cost will be a useful instrument for planning local healthcare systems.

The Stroke Mortality and Morbidity Study (Estudo de Mortalidade e Morbidade do Acidente Vascular Cerebral, EMMA) was designed to apply the three phases of the WHO Steps Stroke approach in an area of the city of São Paulo. ${ }^{21}$ For the purposes of determining stroke prevalence, we translated, adapted, validated and applied a simple stroke symptom questionnaire that had been created by researchers working on the MONICA study (MONItoring Trends and Determinants of CArdiovascular Diseases) in order to examine cognitive function. This MONICA ancillary study was named Memory and Morbidity among Augsburg Elderly (MEMO). ${ }^{22}$ The present paper addresses the validation of this individual stroke symptom questionnaire for step 3, using an interview by a board-certified neurologist as the gold standard.

\section{METHODS}

The WHO Steps Stroke approach, with its three steps, is the reference for the EMMA study. It was planned to investigate the burden of stroke among inhabitants of Butantá. This is an area in the western zone of the city of São Paulo, consisting of six districts and encompassing a population of approximately 420,000 inhabitants with one community hospital owned by the University and 14 affiliated primary care units (four of them running the Family Health Program). The communitybased hospital implemented step 1 in May 2006. The analyses on mortality data for step 2 were completed in 2006. Step 3 was completed in 2008 , within the coverage area of one primary care unit. Further data on the design and concept of the EMMA project can be obtained elsewhere. ${ }^{21}$

The primary care unit (Unidade Básica de Saúde, UBS) chosen for step 3 was in the Jardim São Jorge area. Approximately 15,000 people live in this area, and they receive healthcare under the Family Health Program, a federal health strategy in which a lay community health worker visits all the families in his/her area every month, under nurse/ physician supervision. Six family physicians attend cases at this primary care unit, and each physician works with six community health workers. Each health worker has the task of visiting all the households in his/ her area once a month. This area was previously charted when the program was implemented in the Butantã district, and it has been continually brought up to date when families move away or new families come to the area.

The questionnaire was based on the Memo Study, ${ }^{22}$ which was applied door-to-door or by mail to investigate the prevalence of stroke. The Portuguese version translated from English (PAL) is shown in Annex 1.

Data collection was done in two phases. Most of the families were contacted at the time of the monthly visit in February 2008. If no one in the family could be contacted in February 2008, a second visit in March or even a third visit in April-June 2008 was made. The community health workers were trained by a physician (IMA) to apply a questionnaire, in order to identify possible stroke patients at the monthly visits to families. The screening procedure was a face-to-face interview with one of the people living in the house, generally the mother/spouse, who answered questions about stroke symptoms on behalf of everyone over the age of 35 years who was living in the house. The form included five questions on stroke symptoms, in relation to limb weakness (arm or leg), facial weakness, speech problems, sensory disorders and impaired vision (Annex 1).

When someone in the house screened positive, the community health worker applied a longer questionnaire to the index subject on the same day or another day, asking again about stroke symptoms, sociodemographic characteristics, frequent comorbidities and use of medication. To facilitate comprehension, two pictures showing the appearance of facial weakness and the most common visual impairments in stroke patients were presented by the interviewer. The questionnaire also asked the patient whether he/she had had a stroke and, if the answer was yes, where he/she had been treated by a doctor, whether a computed tomography $(\mathrm{CT})$ scan had been performed and what type of stroke the patient had had (Annex 2).

\section{Validation study}

The entire protocol was approved by the Institutional Review Board of Hospital Universitário of the Universidade de São Paulo. The sample size for the validation study was calculated based on a estimated prevalence of a positive individual questionnaires of $25 \%$, ranging from $5 \%$ to $45 \%$, with a $95 \%$ confidence interval. The sample was divided into two groups: (1) with low or no risk of stroke and (2) with moderate to high risk of stroke. The sample size was calculated as 18 in each group. Thus, out of the 579 individuals who screened positive, 60 were randomly selected, including 25 into group 1 (low or no risk of stroke) and 
35 into group 2 ( 25 with moderate risk and 10 with high risk of stroke). Of these 60 individuals, 36 agreed to cooperate and signed the second research agreement.

We took the questionnaire result to be positive when the participant gave positive responses to two or more questions, either about stroke symptoms (out of five questions) or presence of stroke (one question), with confirmation from a physician; or when he/she gave at least three positive responses (out of the six questions), whether confirmed by a physician or not.

All the randomly selected participants were invited to come for a neurological interview in the hospital setting. They were contacted by phone or were visited by a member of the research team. All the neurological interviews were conducted by the same neurologist, who was blinded to the results from the questionnaire. Medical diagnoses of stroke were made based on the clinical interview, neurological examination and review of previous medical records, and on the individuals' responses on the National Institute of Health Stroke Scale (NIHSS) and the Modified Rankin scale for evaluating the presence of disabilities.

\section{Diagnostic criteria}

Stroke was defined in accordance with the WHO criteria as "an episode with sudden or rapid onset with focal brain dysfunction resulting from occlusive or hemorrhagic lesions of the vascular supply of the brain or global brain dysfunction which persisted for more than 24 hours and no apparent cause other than vascular origin". ${ }^{19}$ Stroke subtypes were defined based on information from the participants, medical records or analysis of previous CT scans.

\section{Statistical methods}

The results were presented as proportions or means with standard deviation. The chi-square and analysis of variance (ANOVA) tests were used as appropriate. The sensitivity, specificity, positive and negative predictive values, accuracy and positive and negative likelihood ratios were calculated by comparing the responses to the questionnaire with the gold standard represented by the neurological interview and consultation of the previous hospital medical records. We calculated sensitivity, specificity, predictive values and likelihood ratios for the questionnaire overall and for each item singly. We used the Landis and Kock classification $^{23}$ for the kappa coefficient to assess the level of agreement between the questionnaire and the neurological examination.

\section{RESULTS}

Table 1 shows the general characteristics of the individuals with and without stroke in the sample. For two symptoms, impaired vision and facial weakness, there were no differences between individuals with stroke compared to those without stroke detected by the questionnaire. The scales were administered by the neurologist. There were statistically significant differences between the groups with regard to the presence of limb weakness, speech problems and sensory disorders, and in relation to the scores on the NIHSS and modified Rankin scales.
Table 2 shows the sensitivity, specificity, positive and negative predictive value and positive and negative likelihood ratio results for all of the questionnaires, taking the established criteria into account. The results showed reasonable sensitivity and high specificity. The positive likelihood ratio was 12.9 and the negative likelihood ratio was 0.29 . The questionnaire failed especially in mild cases of stroke in which the patients presented symptoms with low levels of disability or no disabilities at all. Four patients (18.2\%) with no previous history of stroke were diagnosed as cases of stroke after neurological examination.

Specific symptoms were considered in the analyses in Table $\mathbf{3}$, and all of them had higher specificity than sensitivity. In contrast to the positive likelihood ratio for the overall questionnaire, these ratios for each symptom alone were relatively lower. The assessment of interobserver variability, i.e. between the questionnaire criteria and the diagnosis made by the board-certified neurologist was calculated by means of the kappa coefficient. Using the Landis and Kock classification ${ }^{25}$ for the level of agreement shown by the kappa coefficient, we found that the level was "substantial" for the questions overall; "moderate" for "limb weakness" and for the category "at least one question addressing stroke symptoms"; "fair" for "facial weakness" and for "speech problems"; and "poor" for "sensory disorders" and "impaired vision".

Table 1. Characteristics of participants with and without stroke according to questionnaire submitted to validation with a neurological interview and analysis of previous medical history

\begin{tabular}{lccc}
\cline { 1 - 2 } & \multicolumn{2}{c}{$\begin{array}{c}\text { Positive screening } \\
\text { questionnaire }\end{array}$} & P \\
\cline { 2 - 3 } & $\begin{array}{c}\text { Yes } \\
(n=14)\end{array}$ & $\begin{array}{c}\text { No } \\
(n=22)\end{array}$ & \\
\hline Age (years) & $57.2(11.1)$ & $52.3(12.3)$ & 0.23 \\
\hline Women (\%) & 57.1 & 77.3 & 0.27 \\
\hline number of symptoms reported & 2.2 & 0.4 & $<0.0001$ \\
\hline paralysis & 78.6 & 9.1 & $<0.0001$ \\
\hline facial weakness & 28.6 & 9.1 & 0.18 \\
\hline difficult to speech & 35.7 & 0 & 0.005 \\
\hline sensory disorders & 42.9 & 9.1 & 0.036 \\
\hline visual disturbances & 35.7 & 13.6 & 0.22 \\
\hline medical history of stroke & 78.6 & 0 & $<0.0001$ \\
\hline medical diagnosis & 78.6 & 0 & $<0.0001$ \\
\hline medical plus computadorized tomography & 50.0 & 4.5 & 0.003 \\
diagnosis & & & \\
\hline National Institutes of Health Stroke Scale & 2.6 & 1.1 & 0.027 \\
\hline Modified Rankin Scale & 0.86 & 0.14 & 0.001 \\
\hline
\end{tabular}

Table 2. Sensitivity, specificity, positive and negative predictive value, positive and negative likelihood ratio and kappa coefficient of the EMMA (Estudo de Mortalidade e Morbidade do Acidente Vascular Cerebral) questionnaire $\left({ }^{*}\right)$ for stroke diagnosis using clinical interview with a board certified neurologist as a gold standard.

\begin{tabular}{lcccc}
\hline & & \multicolumn{2}{c}{ Stroke (neurological evaluation) } & Total \\
\hline \multirow{2}{*}{ EMMA Questionnaire $\left(^{*}\right)$} & Yes & No & \\
\cline { 2 - 5 } & Yes & 13 & 1 & 14 \\
\hline \multirow{2}{*}{ Total } & No & 5 & 17 & 22 \\
\hline
\end{tabular}

Sensitivity $=72.2 \%$, Specificity $=94.4 \%$, Positive Predictive Value $=92.9 \%$, Negative Predictive Value $=77.3 \%$, Accuracy $=83.3 \%$, Positive Likelihood Ratio $=12.9$, Negative Likelihood Ratio $=0.29$, kappa $=0.67$ $\left({ }^{*}\right)$ Portuguese version of the Memo Study (reference \# 23). See annex 2. 
Table 3. Performance of sensitivity, specificity, positive and negative predictive values, positive and negative likelihood ratios and kappa for each symptom separately and the use of just one question for stroke confirmation

\begin{tabular}{|c|c|c|c|c|c|c|}
\hline Symptom & $\begin{array}{l}\text { Limb } \\
\text { weakness }\end{array}$ & $\begin{array}{c}\text { Facial } \\
\text { Weakness }\end{array}$ & $\begin{array}{l}\text { Articulation } \\
\text { problems }\end{array}$ & $\begin{array}{l}\text { Sensory } \\
\text { disorders }\end{array}$ & $\begin{array}{l}\text { Impaired } \\
\text { vision }\end{array}$ & $\begin{array}{c}\text { At least } \\
1 \text { question addressing stroke symptoms }\end{array}$ \\
\hline Sensitivity ((\%) & 57.9 & 26.3 & 26.3 & 31.6 & 26.3 & 57.8 \\
\hline Specificity (\%) & 88.2 & 94.1 & 100.0 & 88.2 & 82.3 & 100 \\
\hline Positive predictive value (\%) & 84.6 & 83.3 & 100.0 & 75 & 62.5 & 100 \\
\hline Negative predictive value (\%) & 65.2 & 53.3 & 45.2 & 53.6 & 50.0 & 68.0 \\
\hline Positive likelihood ratio & 4.9 & 4.5 & $+\infty$ & 2.7 & 1.5 & $+\infty$ \\
\hline Negative likelihood ratio & 0.48 & 0.78 & 0.74 & 0.76 & 0.90 & 0.58 \\
\hline Kappa & 0.45 & 0.20 & 0.25 & 0.19 & 0.08 & 0.57 \\
\hline
\end{tabular}

Kappa $=$ coefficient of concordance beyond chance .

\section{DISCUSSION}

The results showed that it is possible to screen for stroke using a questionnaire about symptoms and previous medical diagnoses of stroke that can be applied by community health workers within the setting of primary care units and the Family Health Program. We used a screening instrument originally to evaluate the sensitivity of a simple screening question in comparison with a five-item questionnaire for diagnosing stroke in the MEMO Study. ${ }^{22}$ We found sensitivity of $57.8 \%$ for the diagnosis of stroke using only a single stroke question, compared with $65.8 \%$ in the original study. Limb weakness was the most frequent stroke symptom in both studies. However, the sensitivity was higher in our study $(57.9 \%$ versus $39.5 \%)$. The least sensitive symptoms in the questionnaire were facial weakness, speech problems and impaired vision. These data are similar to the findings from the MEMO study, with the exception of impaired vision, which in their study was as sensitive as limb weakness. One possible explanation for this is that untreated ocular refractive errors are very common in Brazil due to the shortage of ophthalmologists in the most deprived areas and given that optometrists are prohibited from treating refractive errors.

Other studies worldwide have attempted to evaluate the prevalence of stroke in population-based samples using questionnaires. The Sicilian Epidemiological Study in 1987 was a two-phase epidemiological survey that evaluated the frequency and distribution of stroke and other neurological disorders. All the individuals who screened positive in phase one were evaluated by a neurologist in phase $2 .{ }^{24,25}$ In Latin America, a door-todoor survey was carried out in Junín, Argentina, in two stages: in stage 1, a responsible adult in the house, preferably the mother or spouse answered questions about stroke on behalf of all members of the family. Stage 2 included a complete neurological examination on all the individuals who screened positive in phase $1 .{ }^{26}$ Another door-to-door survey in Bolivia in 1994 studied prevalence of stroke in a two-phase survey. In phase 1, a sample from rural communities that was selected from 10 areas in Cordillera Province was screened door-to-door to identify individuals with possible stroke, using a questionnaire and simple tasks as the instruments. In phase 2 , all the individuals who screened positive underwent a complete neurological examination. ${ }^{27}$ We also performed a two-phase study. However, in the second phase, a more detailed questionnaire was applied to all the adults aged over 35 years, and only the cases that participated in the validation study were examined by a neurologist. We also used the structure of the Family Health Program.
These two points made the present study less expensive than previous studies in which a neurologist examined all the individuals who screened positive. For a city like São Paulo, in which most of the neurologists are concentrated in the central and richer areas and are not available for research in primary care settings, this strategy seems more cost-effective. It can be used periodically to investigate changes in stroke frequency in neighborhoods of São Paulo, a city in which stroke is the third greatest cause of death, closely following coronary heart disease and cancer. ${ }^{5,8}$

One further important point is that our questionnaire is not very sensitive for diagnosing mild cases of stroke. One consequence of this is that the prevalence of stroke in this population was probably underestimated. However, this questionnaire is capable of selecting the most severe cases with greater degrees of disability, thus making it possible to identify the cases that need more rehabilitation support. Finally, we need to emphasize that our questionnaire was not applied as a "Questionnaire for Verifying Stroke-free Status", ${ }^{28}$ of the type that is used during the baseline phase of randomized controlled trials. Questionnaires like the stroke symptom questionnaire of the EMMA study and others used elsewhere $e^{25,28}$ are only to be applied for epidemiological surveys, epidemiological studies and clinical trials, by trained assistant researchers under neurological supervision. The use of this questionnaire for clinical purposes or by the hospital gatekeeper unit is strongly discouraged by the present authors.

\section{CONCLUSIONS}

We conclude that it is possible to use a questionnaire applied by lay interviewers to identify cases of stroke using the structure of the Family Health Program. The data obtained could be used for strategic planning of primary care in the study areas.

\section{REFERENCES}

1. Lolio CA, Laurenti R. Tendência da mortalidade por doenças cerebrovasculares em adultos maiores de 20 anos de idade no Município de São Paulo (Brasil), 1950 a 1981 [Tendencies of mortality due to cerebrovascular diseases in adults over 20 in the municipality of São Paulo (Brazil), 1950 to 1981]. Rev Saúde Pública. 1986;20(5):343-6.

2. Gomes MM, Becker RA. Tendências da mortalidade por doenças cerebrovasculares no Brasil -1979 a 1986 [Tendencies of mortality by cerebrovascular diseases in Brazil - 1979 to 1986]. Rev Bras Neurol. 1990;26(Supl 1):5s-9s.

3. Lotufo PA, Lolio CA. Tendência da mortalidade por doença cerebrovascular no Estado de São Paulo: 1970 a 1989 [Trends of mortality by cerebrovascular disease in the State of São Paulo: 1970 to 1989]. Arq Neuropsiquiatr. 1993;51(4):441-6. 
4. Lessa. I. Trends in relative mortality from cerebrovascular diseases in Brazilian state capitals, 1950-1988. Bull Pan Am Health Organ. 1995;29(3):216-25.

5. Lotufo PA, Benseñor IM. Trends of stroke subtypes mortality in Sao Paulo, Brazil (19962003). Arq Neuropsiquiatr. 2005;63(4):951-5.

6. Lotufo PA, Goulart AC, Bensenor IM. Race, gender and stroke subtypes mortality in Sao Paulo, Brazil. Arq Neuropsiquiatr. 2007;65(3b):752-7.

7. André C, Curioni $\mathrm{CC}$, Braga da Cunha C, Veras R. Progressive decline in stroke mortality in Brazil from 1980 to 1982, 1990 to 1992, and 2000 to 2002. Stroke. 2006;37(11):2784-9.

8. Lotufo PA, Benseñor IM. Stroke mortality in Brazil: one example of delayed epidemiological cardiovascular transition. Int J Stroke. 2009;4(1):40-1.

9. Christensen MC, Valiente R, Sampaio Silva G, et al. Acute treatment costs of stroke in Brazil. Neuroepidemiology. 2009;32(2):142-9.

10. Carod-Artal FJ, Ferreira Coral L, Trizotto DS, Menezes Moreira C. Poststroke depression: prevalence and determinants in Brazilian stroke patients. Cerebrovasc Dis. 2009;28(2):15765.

11. Carod-Artal FJ, Ferreira Coral L, Trizotto DS, Menezes Moreira C. Burden and perceived health status among caregivers of stroke patients. Cerebrovasc Dis. 2009;28(5):472-80.

12. Carod-Artal FJ, Trizotto DS, Coral LF, Moreira CM. Determinants of quality of life in Brazilian stroke survivors. J Neurol Sci. 2009;284(1-2):63-8.

13. Lessa I, Bastos CA. Epidemiology of cerebrovascular accidents in the city of Salvador, Bahia, Brazil. Bull Pan Am Health Organ. 1983;17(3):292-303.

14. Minelli C, Fen LF, Minelli DP. Stroke incidence, prognosis, 30-day, and 1-year case fatality rates in Matão, Brazil: a population-based prospective study. Stroke. 2007;38(11):2906-11.

15. Cabral NL, Gonçalves AR, Longo AL, et al. Incidence of stroke subtypes, prognosis and prevalence of risk factors in Joinville, Brazil: a 2 year community based study. J Neuro Neurosurg Psychiatry. 2009;80(7):755-61.

16. Cabral NL, Gonçalves AR, Longo AL, et al. Trends in stroke incidence, mortality and case fatality rates in Joinville, Brazil: 1995-2006. J Neurol Neurosurg Psychiatry. 2009;80(7):749-54.

17. Monteiro CA, Moura EC, Jaime PC, et al. Monitoramento de fatores de risco para doenças crônicas por entrevistas telefônicas [Surveillance of risk factors for chronic diseases through telephone interviews]. Rev Saúde Pública = J Public Health. 2005;39(1):47-57.

18. Pereira ABCNG, Alvarenga H, Pereira Júnior RS, Barbosa MTS. Prevalência de acidente vascular cerebral em idosos no Município de Vassouras, Rio de Janeiro, Brasil, através do rastreamento de dados do Programa Saúde da Família [Stroke prevalence among the elderly in Vassouras, Rio de Janeiro State, Brazil, according to data from the Family Health Program]. Cad Saúde Pública = Rep Public Health. 2009;25(9):1929-36.

19. Truelsen T, Bonita R, Jamrozik K. Surveillance of stroke: a global perspective. Int J Epidemiol. 2001;30 Suppl 1:S11-6.

20. Truelsen T, Heuschmann PU, Bonita R, et al. Standard method for developing stroke registers in low-income and middle-income countries: experiences from a feasibility study of a stepwise approach to stroke surveillance (STEPS Stroke). Lancet Neurol. 2007;6(2):134-9.

21. Goulart AC, Bustos IR, Abe IM, et al. A Stepwise Approach to Stroke Surveillance in Brazil: the EMMA (Estudo de Mortalidade e Morbidade do Acidente Vascular Cerebral) Study. Design and Concepts. Int J Stroke. 2010;5(4):284-9.

22. Berger K, Hense HW, Rothdach A, Weltermann B, Keil U. A single question about prior stroke versus a stroke questionnaire to assess stroke prevalence in populations. Neuroepidemiology. 2000;19(5):245-57.

23. Landis JR, Koch GG. The measurement of observer agreement for categorical data. Biometrics. 1977;33(1):159-74.

24. Meneghini F, Rocca WA, Grigoletto F, et al. Door-to-door prevalence survey of neurological diseases in a Sicilian population. Background and methods. The Sicilian Neuro-Epidemiologic Study (SNES) Group. Neuroepidemiology. 1991;10(2):70-85.

25. Meneghini F, Rocca WA, Anderson DW, et al. Validating screening instruments for neuroepidemiologic surveys: experience in Sicily. Sicilian Neuro-Epidemiologic Study (SNES) Group. J Clin Epidemiol. 1992;45(4):319-31.

26. Melcon $\mathrm{CM}$, Melcon MO. Prevalence of stroke in an Argentine community. Neuroepidemiology. 2006;27(2):81-8.

27. Nicoletti A, Sofia V, Giuffrida S, et al. Prevalence of stroke: a door-to-door survey in rural Bolivia. Stroke. 2000;31(4):882-5.

28. Meschia JF, Brott TG, Chukwudelunzu FE, et al. Verifying the stroke-free phenotype by structured telephone interview. Stroke. 2000;31(5):1076-80.

Acknowledgements: Dr. Lotufo and Dra. Benseñor are recipients of an award for established investigators from Conselho Nacional de Pesquisa, Brasília, Brazil. The EMMA (Estudo de Mortalidade e Morbidade do Acidente Vascular Cerebral) project was funded by Conselho Nacional de Pesquisa, Brasília, Brazil, and Fundação de Amparo à Pesquisa do Estado de São Paulo, São Paulo, Brazil
Sources of funding: The EMMA project (Estudo de Mortalidade e Morbidade do Acidente Vascular Cerebral) was funded by the Conselho Nacional de Pesquisa (CNPq - universal announcement, grant 47219/2004-0) and by the Fundação de Amparo à Pesquisa do Estado de São Paulo (Fapesp - grant 05/03061-4R), along with statistical support from Fundação Sistema Estadual de Estatísticas do Estado de São Paulo (SEADE). Conflict of interest: Dr. Lotufo received grants for enrolling participants for the Clarity (Bristol-Myers Squibb) and Plato (Astra-Zeneca) trials, and for the ongoing Axiom (Takeda) and Trilogy (Eli-Lilly) trials, all of them addressing treatment of acute coronary syndrome.

Date of first submission: January 18, 2010

Last received: June 11, 2010

Accepted: June 18, 2010.

\section{Address for correspondence:}

Isabela Martins Benseñor

Hospital Universitário

Av. Lineu Prestes, 2.565

São Paulo (SP) - Brasil

CEP 05508-000

Tel. (+55 11) 3091-9300

Fax. (+55 11) 3091-9241

E-mail: isabensenor@hu.usp.br

Annex 1: Screening questionnaire

Data:
Número de Família/ Equipe ___ Endereço__ Celefone __ CEP
Bairro do entrevistado

Nome do entrevistado

\begin{tabular}{|l|l|l|l|l|l|l|l|l|l|}
\hline & \multirow{2}{*}{ Prontuário } & Nome & $\begin{array}{c}\text { Data de } \\
\text { Nascimento }\end{array}$ & sexo (F/M) & \multicolumn{5}{|c|}{ Rastreamento positivo? } \\
\hline & & & & & Data & Data & Data & Data & Data \\
\hline 1 & & & & & & & & & \\
\hline 2 & & & & & & & & & \\
\hline 3 & & & & & & & & & \\
\hline 4 & & & & & & & & & \\
\hline 5 & & & & & & & & & \\
\hline 6 & & & & & & & & & \\
\hline 7 & & & & & & & & & \\
\hline 8 & & & & & & & & & \\
\hline 9 & & & & & & & & & \\
\hline 10 & & & & & & & & & \\
\hline
\end{tabular}

1. Alguma vez o(a) senhor(a) já teve paralisia ou fraqueza de um lado todo do corpo, de um braço ou de uma perna?

2. Alguma vez o(a) senhor(a) já ficou com o canto da boca torta, como mostra a foto 1 , sem conseguir trazê-la ao normal voluntariamente?

3. Alguma vez o(a) senhor(a) já teve alteração da fala, ou problema de conversar com alguém por não conseguir articular, pronunciar as palavras ou sentenças corretamente?

4. Alguma vez o(a) senhor(a) já teve adormecimento ou perda da sensibilidade de um lado do corpo, de um braço ou uma perna, com duração maior que um dia inteiro?

5. Alguma vez o(a) senhor(a) já teve algum dos sintomas visuais da foto 2 , em um ou ambos os olhos?

6. Alguma vez algum médico disse que o(a) senhor(a) já teve um derrame ou acidente vascular cerebral? 
Annex 2: Second questionnaire: for positive cases

1. Número do questionário:

2. Entrevistador:

3. Data _ _ _ _

4. Identificação:

5. Número da família (área/micro-área):

6. Nome

7. Endereço:

8. Telefone

9. Data de nascimento:___ 10. Sexo: F/ M

$\begin{array}{llll}\text { 11. Raça: } 1 \text {. branco } & \text { 2. negro } & \text { 3. pardo asiático } & \text { 5. outro }\end{array}$

12. Nível Educacional:

1. sem estudo formal

2. fundamental incompleto

3. fundamental completo

4. médio incompleto

5. médio completo

6. superior completo

7. pós-graduação

8. sem informação

13. Qual o principal trabalho da pessoa nos últimos 12 meses?

1. funcionário público

2. funcionário de empresa privada

3. trabalhador liberal

4. trabalhador informa

5. estudante

6. dona de casa

7. aposentado por tempo de serviço

8. aposentado por invalidez

9. desempregado

10. não se aplica

14. Qual a renda familiar média no último ano?

1. por semana

2. ou por mês

3. ou por ano

4. informação negada

15. Alguma vez o(a) senhor(a) já teve paralisia ou fraqueza de um lado todo do corpo, de um braço ou de uma perna?

$\begin{array}{lll}\text { 1. } \operatorname{sim} & \text { 2. não } & \text { 3. não sei }\end{array}$

Se sim: Por favor, descreva resumidamente os sintomas e a sua duração:

Estes sintomas foram tratados por um médico?

$\begin{array}{lll}\text { 1. } \operatorname{sim} & \text { 2. não } & \text { 3. não sei }\end{array}$

Se sim: Quando? Mês Onde?

16. Alguma vez o(a) senhor(a) já ficou com o canto da boca torta, como mostra a foto 1 , sem conseguir trazê-la ao normal voluntariamente?

$\begin{array}{lll}\text { 1. } \operatorname{sim} & \text { 2. não } & \text { 3. não sei }\end{array}$

Se sim: Por favor, descreva resumidamente os sintomas e a sua duração:

Estes sintomas foram tratados por um médico?

$\begin{array}{lll}\text { 1. } \operatorname{sim} & \text { 2. não } & \text { 3. não sei }\end{array}$

Se sim: Quando? Mês ___ Ano Onde?

17. Alguma vez o(a) senhor(a) já teve alteração da fala, ou problema de conversar com alguém por não conseguir articular, pronunciar as palavras ou sentenças corretamente?

$\begin{array}{lll}\text { 1. } \operatorname{sim} & \text { 2. não } \quad \text { 3. não sei }\end{array}$

Se sim: Por favor, descreva resumidamente os sintomas e a sua duração:

Estes sintomas foram tratados por um médico?

$$
\begin{array}{lll}
\text { 1. } \operatorname{sim} & \text { 2. não } & \text { 3. não sei }
\end{array}
$$

Se sim: Quando? Mês Onde?

18. Alguma vez o(a) senhor(a) já teve adormecimento, formigamento ou perda da sensibilidade de um lado todo do corpo, de um braço ou uma perna? $\begin{array}{lll}\text { 1. } \operatorname{sim} & \text { 2. não } & \text { 3. não sei }\end{array}$

Se sim: Por favor, descreva resumidamente os sintomas e a sua duração:
Estes sintomas foram tratados por um médico? $\begin{array}{lll}\text { 1. } \operatorname{sim} & \text { 2. não } & \text { 3. não sei }\end{array}$

Se sim: Quando? Mês Onde?

19. Alguma vez o(a) senhor(a) já teve algum dos sintomas visuais da foto 2 , em um ou ambos os olhos?

$\begin{array}{lll}\text { 1. } \operatorname{sim} & \text { 2. não } & \text { 3. não sei }\end{array}$

Se sim: Por favor, descreva resumidamente os sintomas e a sua duração

Estes sintomas foram tratados por um médico?

$$
\begin{array}{lll}
\text { 1. } \operatorname{sim} & \text { 2. não } & \text { 3. não sei }
\end{array}
$$

Se sim: Quando? Mês Onde?

20. Alguma vez algum médico disse que o(a) senhor(a) já teve um derrame, acidente vascular cerebral ou hemorragia cerebral?

$\begin{array}{lll}\text { 1. } \operatorname{sim} & \text { 2. não } & \text { 3. não sei }\end{array}$

Se sim: Por favor, descreva resumidamente os sintomas e a sua duração

21. Estes sintomas foram tratados por um médico?
1. $\operatorname{sim}$ 2. não
3. não sei

Se sim: Quando? Mês Onde?

22. Onde o (a) senhor (a) foi atendido (a) devido a estes sintomas?

1. asilo/casa de repouso

2. em casa por um médico ou enfermeiro

3. Programa Saúde da Família

4. consulta médica particular

5. consulta médica em posto de saúde (UBS tradicional)

6. pronto-socorro

7. hospital

8. não foi atendido por serviço médico

9. não se aplica

23. Foi feito o diagnóstico de derrame, hemorragia cerebral ou acidente vascular cerebral? $\begin{array}{llll}\text { 1. } \operatorname{sim} & \text { 2. não } & \text { 3. não sei } & \text { 4. não se aplica }\end{array}$

Se sim, responder as questões 24, 25, 26, 27, 28 e 29

24. Que tipo de derrame foi diagnosticado?
1. AVC isquêmico
2. hemorragia intracerebral
3. hemorragia subaracnóidea
4. não sei

25. Como o tipo de derrame foi descoberto?

1. diagnóstico clínico apenas

2. por exames diagnósticos (por exemplo, Tomografia computadorizada, ressonância)

26. 0 (A) senhor(a) recebeu alguma das medicações seguintes?

1. anticoagulantes

2. antidiabéticos

3. anti-agregantes plaquetários

4. medicações para o colestero

5. medicações para pressão alta

6. anticoncepcional

7. outros

27. Qual era a sua situação de vida antes dos sintomas?

1. independente em casa

2. dependente em casa

3. não sei

28. Após o derrame, o (a) senhor (a) foi encaminhado (a) para uma avaliação de fisioterapia?
1. $\operatorname{sim}$ 2. não
3. não sei

29. Após o derrame, o (a) senhor (a) foi encaminhado (a) para uma avaliação de fonoaudiologia?
$\begin{array}{ll}\text { 1. sim 2. não } & \end{array}$
3. não sei 
30. O(A) senhor(a) já tinha sofrido outro derrame? 1. não 2. sim. Quantos?

31. O(A) senhor(a) tem alguma das condições abaixo relacionados?

1. Hipertensão arterial

2. Diabetes mellitus

3. Cardiopatia

4. Tabagismo

5. Dislipidemia

6. Fibrilação arterial

7. Sedentarismo

8. Obesidade

32. Se sim, fazia acompanhamento regular com algum médico? 1. sim. Qual o seu nome? 2. กão

3. não sei

33. Escala de Rankin modificada

0 . Sem nenhum sintoma

1. Sem incapacidade significativa apesar de sintomas: pode fazer todas as atividades habituais

2. Pequena incapacidade: incapaz de fazer todas as atividades habituais prévias, mas capaz de se cuidar sem ajuda

3. Moderada incapacidade: necessita de alguma ajuda, mas anda sozinho

4. Moderada incapacidade: incapaz de andar sozinho e de realizar higiene corporal sem ajuda
5. Grave incapacidade: acamado, incontinente e necessita de constante cuidados de enfermagem

6. Morte

7. Desconhecido

34. Escala de atividades básicas de vida diária

\begin{tabular}{|l|l|l|l|}
\hline \multicolumn{2}{|l|}{ Atividade } & Independente & Score \\
\hline 1 & Banho & $\begin{array}{l}\text { Não recebe ajuda ou somente recebe ajuda } \\
\text { para uma parte do corpo }\end{array}$ & \\
\hline 2 & Vestir-se & $\begin{array}{l}\text { Pega as roupas e se veste sem qualquer ajuda, } \\
\text { exceto para arrumar os sapatos }\end{array}$ & \\
\hline 3 & $\begin{array}{l}\text { Higiene } \\
\text { pessoal }\end{array}$ & $\begin{array}{l}\text { Vai ao banheiro, usa o banheiro, veste-se e re- } \\
\text { torna sem qualquer ajuda (pode usar andador } \\
\text { e bengala) }\end{array}$ & \\
\hline 4 & Transferência & $\begin{array}{l}\text { Consegue deitar na cama, sentar na cadeira } \\
\text { e levantar sem ajuda (pode usar andador e } \\
\text { bengala) }\end{array}$ & \\
\hline 5 & Continência & $\begin{array}{l}\text { Controla completamente urina e fezes } \\
\text { passar manteiga no pão) }\end{array}$ & \\
\hline 6 & Alimentação & $\begin{array}{l}\text { Come sem ajuda (exceto para cortar carne ou } \\
\text { passar ma 0 para não }\end{array}$ & \\
\hline & & Score total, marque 1 para sim e 0 & \\
\hline
\end{tabular}

